\title{
The Effect of Debt to Asset Ratio, Return on Equity, and Current Ratio on Stock Prices of Pharmaceutical Companies Listed on the Indonesia Stock Exchange 2016-2019 Period
}

\author{
Ade Onny Siagian, Hadion Wijoyo, Yoyok Cahyono \\ Universitas Bina Sarana Informatika, Indonesia, STMIK Dharmapala Riau, Universitas \\ Pramita Indonesia ( UNPRI), Indonesia
}

\begin{abstract}
This research aims to determine: The influence of Current Ratio (CR), Debt to Asset Ratio (DAR), and Return on Equity (ROE) either partially or simultaneously on Stock Price of pharmaceutical companies listed on the Indonesia Stock Exchange (IDX) 2016-2019 period. Data were taken from the Indonesia Stock Exchange (IDX) website. Analysis prerequisite test including normality test, multicollinearity, heteroscedasticity, and autocorrelation. Data analysis technique used is multiple linear regression analysis. Statistical results also show that the current ratio (X1) and return on equity (X3) partially have a positive and significant effect on stock prices (Y). Debt to asset ratio (X2) partially does not have a significant effect on stock prices (Y). Simultaneously current ratio (X1), debt to asset ratio (X2), and return on equity (X3) have a positive and significant effect on stock prices (Y).
\end{abstract}

Keywords

Current Ratio (CR), Debt to Asset Ratio (DAR), Harga Saham, Return On Equity (ROE)

\section{Introduction}

The development of the flow of technology and information is developing rapidly, the development of the world economy is very dynamic, including the development and growth of the business world. In order to face the competition that arises as a result of this rapid development, all companies, both domestic and foreign, must also grow and develop rapidly and sustainably in order to gain the trust of investors. One of the ways to attract investors is to register the company's shares in the capital market or better known as going public.

The capital market or stock exchange is a place for buying and selling shares, bonds and securities between companies and individuals or the public. The definition of stock exchange has been defined in Law No. 8 of 1995 concerning the capital market. The definition is that a Stock Exchange is a party that operates a system and / or means of bringing together selling and buying offers of securities of other parties for the purpose of trading securities between them. The Indonesian government has provided a capital market in Indonesia known as the Indonesia Stock Exchange (BEI). The Indonesia Stock Exchange is the result of a merger between the Jakarta Stock Exchange (BEJ) and the Surabaya Stock Exchange (SSE). The merged exchange began operating on December 1, 2007.

The pharmaceutical sector is one of the company sectors listed on the Indonesia Stock Exchange. The pharmaceutical sector has a very important role in health sector reform. According to data from the BPOM as of 30 June 2018, there are 209 pharmaceutical companies registered in Indonesia that have a CPOB (Good Manufacturing Practice) certificate, while 10 pharmaceutical companies are listed on the IDX and go public.

Indonesia has great potential for pharmaceutical companies. This was proven at the beginning of 2019, where the positive movement caused by the strengthening of the rupiah benefited companies that depend on imported raw materials, one of which is companies in the pharmaceutical sector. It is common knowledge that the majority of raw materials for drug production come from imports.

One of the indicators for measuring the value of companies that go public is the stock price of the company. Stock price movements have a reciprocal relationship with the company's financial performance. The company's financial performance is an important factor that affects the ups and downs of the company's stock prices. The level of stock prices also affects the financial performance of a company.

The movement of stock prices in the capital market is strongly influenced by many factors, such as the company's financial statements, the level of supply and demand for shares, the rate of inflation, interest rates, government policies, the level of risk, politics and security of a country. The company's financial statements are the factors that most influence stock movements. 
Before make an investment, first investors will analyze the condition of the company's financial statements in the past, whether the financial position that represents the company's reality and potential performance will continue. In analyzing the financial performance of investors using financial reports as their reference. One of the ways to analyze financial reports that investors usually do before investing is fundamental analysis. The main idea of this approach is that share prices are influenced by the company's financial statements.

Based on above description, it is necessary to conduct research related to factors that can affect stock movements such as Current Ratio (CR), Debt to Asset Ratio (DAR), and Return on Equity (ROE). (Basalama, I. S., Murni, S., dan Sumarauw, 2017)

Current Ratio is a ratio that shows the ability of the company's current assets to meet short-term liabilities with current assets owned.

Debt to Asset Ratio is a debt ratio that is used to measure the ratio between total debt and total assets. The higher of the ratio value, the more funding the company's operations will be with debt loans.

Return on Equity is a ratio calculation that shows a company's ability to generate net profit using its own capital and generate net income available to owners or investors. The higher of the ROE value, the higher of the company value.

\section{Literature Review and Hypothesis}

\subsection{Financial statements}

Company financial reports should not be made carelessly. Company reports must be prepared and prepared in accordance with applicable rules and standards. This is must be done so that the financial statements can be understood easily and are useful for its users.

According to Kasmir, (2016), "Financial reports are reports that show the company's current financial condition or within a certain period. The company's current condition is the company's financial condition on a certain date (for balance sheet) and a certain period (for profit or loss)."

\subsection{Purpose of Financial Statements}

Every financial report certainly has a purpose. In practice, there are several goals to be achieved, especially for company owners. In general, financial statements aim to provide information about financial conditions. According to Kasmir, (2016), "Some of the purposes for making or preparing financial reports are:

a. Provide information about the types and amounts of assets the company currently owns.

b. Provide information about the types and amounts of liabilities and capital the company currently has.

c. Provide information about the type and amount of income earned in a certain period.

d. Provide information about the types and amounts of costs incurred by the company in a certain period.

e. Provide information about the changes that occur in the company's assets, liabilities and capital.

f. Provide information about the performance of company management in a period.

g. Provide information about notes to financial statements.

h. Other financial information.

\subsection{Types of Financial Statements}

There are several types of financial reports made by companies. Each of these financial statements has its own meaning in seeing the company's financial condition.

According to Kasmir, (2016), "In general, there are five types of financial reports that are usually prepared, namely balance sheets, income statements, changes in capital reports, cash flow reports, notes reports on financial statements."

\subsection{Financial Statement Analysis}

Financial statement analysis is analytical tools and techniques for general purpose financial reports and related data to produce useful estimates and conclusions. Financial statement analysis reduces reliance on hunches, guesswork, and intuition in decision making, and reduces uncertainty in analysis.

According to Harahap, (2015), "financial statement analysis is an effort to find the relationship between various posts in the company's financial statements."

\subsection{Purpose of Financial Statement Analysis}

Activities in financial statement analysis can be carried out by determining and measuring the items contained in a financial report. Then, financial statement analysis can also be done by analyzing financial reports that are owned in one period. In addition, financial statement analysis can also be carried out between several periods. 


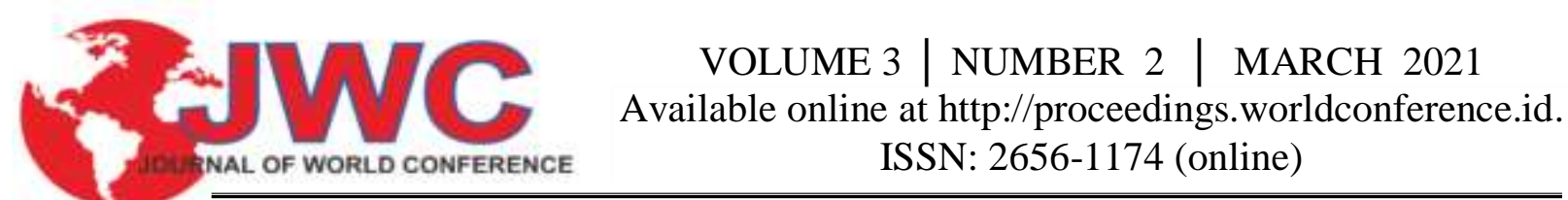

According to Kasmir, (2016), "There are several goals and benefits for various parties with the analysis of financial statements. In general, it is said that the objectives and benefits of financial statement analysis are:

a. To find out the company's financial position in a certain period, whether it is assets, liabilities, capital or business results that have been achieved for several periods.

b. To find out what weaknesses the company lacks.

c. To know the strengths - the strengths that are owned.

d. To find out what corrective steps need to be taken in the future in relation to the company's current financial position.

e. To assess future management performance whether it needs refresher or not because it is considered successful or failed.

f. Can also be used as a comparison with similar companies regarding the results they have achieved.

\subsection{Financial Statement Analysis Methods}

To perform financial statement analysis, appropriate analytical methods and techniques are required. The purpose of determining this method is so that the financial reporting method can provide maximum results. In addition, users of the analysis results can easily interpret them. According to Kasmir, (2016), "In practice, there are two types of financial statement analysis methods commonly used, namely as follows:

1. Vertical Analysis (Static)

Vertical analysis is an analysis that is carried out on only one financial reporting period. The analysis was carried out between the existing items in one period. The information obtained is for one period only and there is no known progress from period to period.

2. Horizontal (Dynamic) Analysis

Horizontal analysis is an analysis carried out by comparing financial reports for several periods. From the results of this analysis, we can see the company's development from one period to another. "

\subsection{Current Ratio}

The elements used in the calculation of working capital can be expressed in a ratio that compares total current assets and current liabilities. This ratio is called the Current Ratio.

According to Kasmir, (2016), "Current Ratio is a ratio to measure the company's ability to pay shortterm obligations or debts that are due immediately when they are collected as a whole."

In other words, how many current assets are available to cover short-term liabilities that are due soon. Current Ratio can also be considered as an indicator of a company's security level.

\subsection{Debt to Asset Ratio}

Debt to Asset Ratio is one of the solvency ratios used to measure the solvency level of a company.

According to Kasmir, (2016), "the solvency ratio is a ratio used to measure the extent to which company assets are financed with debt."

A company is said to be solvable if the company has sufficient assets and wealth to pay its debts. This ratio shows the amount of total debt to the total assets owned by a company. This ratio is the percentage of funds provided by creditors for the company.

According to Kasmir, (2016), "Debt to Asset Ratio is a debt ratio used to measure the ratio between total debt and total assets."

In other words, how much the company's assets are financed by debt or how much does the company's debt affect asset management.

\subsection{Return On Equity} profit."

According to Kasmir, (2016), "The profitability ratio is a ratio to assess a company's ability to seek

Profitability ratios can also describe a measure of the level of management effectiveness of a company. The use of profitability ratios can be done by using comparisons between the various components in the financial statements, especially the income statement and balance sheet financial statements. The purpose of using this ratio is so that the company can find out the development of the company within a certain period of time, either decrease or increase, as well as to find the causes of these changes. One of the ratios that includes the profitability ratio is return on equity.

According to Herry, (2016), "Return on equity is a ratio that shows how much equity contributes to creating net income."

Return on equity is considered as a representative of shareholder wealth or company value. The higher the value of this ratio, the better the company value. 


\section{\begin{tabular}{ll|l|l}
3 & VOLUME 3 & NUMBER 2 & MARCH 2021
\end{tabular} \\ Available online at http://proceedings.worldconference.id. ISSN: 2656-1174 (online)}

\subsection{Stock}

All companies listed on the stock exchange are called public or go public companies. In order to meet the requirements stipulated in the PT Law in Indonesia, the public company added the abbreviation "tbk" which means open. The legal entity of a public company is in the form of a PT (Limited Liability Company), which means that each company has limited rights and obligations on each sheet of sero that is controlled. This means that sero holders do not have joint responsibility for the legal obligations arising from the company.

How much the rights and responsibilities of the companies are manifested in the amount of rupiah stated in the shares. Thus the number of shares (sero) controlled by an investor represents a form of ownership in a public company in the form of PT.

According to Desmond, (2014), "The definition of shares is a sign of a statement or ownership in a company."

\section{Research Methods}

This research was conducted with data available on the Indonesia Stock Exchange which was obtained using electronic research methods and literature research in order to obtain other information through internet access on the Indonesia Stock Exchange (IDX) website. With the aim of knowing the effect of Current Ratio, Debt to Asset Ratio, and Return On Equity on Stock Prices in pharmaceutical companies listed on the Indonesia Stock Exchange during the period 2015 to 2018. The variables in this study consisted of independent variables, namely Current Ratio, Debt to Asset Ratio, and Return On Equity, while Stock Price is the dependent variable. Primary data in this study is data that is collected, observed and recorded in the form of a recap of the calculation of ratios and stock prices of pharmaceutical companies listed on the IDX for the period 2016-2019. Meanwhile, secondary data used in this research is data in the form of annual financial reports (audited) of pharmaceutical companies listed on the IDX for the period 2016-2019 which are downloaded through the Indonesia Stock Exchange website. This research technique uses SPSS version 25 using normality test, classical assumption test and multiple regression test and hypothesis testing.

\section{Research Results And Discussion}

1. Determination Coefficient Test

The coefficient of determination test is used to determine how much the percentage of the contribution of the influence of the independent variables simultaneously (simultaneously) to the independent variable. Following are the results of the coefficient of determination test. The coefficient of determination R Square is 0.427 or $42.7 \%$, meaning that the effect of Current Ratio, Debt to Asset Ratio, and Return On Equity on Stock Prices in pharmaceutical companies is $42.7 \%$, while the remaining $57.3 \%$ is influenced by other variables that are not mentioned in this research model.

2. Partial Test (t)

This partial test is to find out how much influence each independent variable has on the dependent variable, how far is the influence of one variable or explanatory variable variables individually able to explain the dependent variable. The hypothesis in this study is that the CR, DAR, and ROE factors partially have a significant effect on stock prices in pharmaceutical companies listed on the IDX. can be concluded as follows:

Whereas the current ratio is partially and significantly influential on stock prices so that the hypothesis can be accepted.

Whereas the debt to asset ratio partially has no and insignificant effect on stock prices so that the hypothesis can be accepted.

Whereas return on equity partially has a significant effect on stock prices so that the hypothesis can be accepted.

3. Simultaneous Test (F)

This F-test is used to calculate whether together (simultaneously) the existing independent variables have an effect on the dependent variable. The hypothesis in this study is that the CR, DAR, and ROE factors simultaneously have a significant effect on stock prices in pharmaceutical companies listed on the Indonesia Stock Exchange for the period 2016-2019.

$F$ count of 7,957 with a significance level of 0,000 . because the value of $F$ count $>F$ table $(7.957>2.89)$ and the significance value is smaller than the significance level $(0.000<0.005)$, the decision taken is to reject Ho and accept Ha. This means that the variables CR, DAR and ROE simultaneously have a significant effect on stock prices in pharmaceutical companies. (Tumonggor, M., Murni, S., dan Rate, 2017)

\section{Conclusions and Suggestions}

1. Based on the results of simultaneous hypothesis testing (statistical $F$ test), it shows that the current ratio, debt to asset ratio, and return on equity variables together have a significant effect on the stock prices of pharmaceutical companies listed on the Indonesia Stock Exchange in the 2016 period - 2019. The value of 
the coefficient of determination (R Square) is 0.427 , which means that the effect of the current ratio, debt to asset ratio, and return on equity on the stock price of pharmaceutical companies listed on the IDX for the period 2016 - 2019 is $42.7 \%$, while the rest $57.3 \%$ is influenced by other variables not mentioned in this research model.

2. Based on the results of partial hypothesis testing (statistical t test) shows that:

a. Current ratio variable with a significance level of $0.009(0.9 \%)$, which means the value is smaller than the significance level of $0.05(5 \%)$. This shows that the current ratio has a significant effect on the stock price of pharmaceutical companies listed on the Indonesia Stock Exchange for the period 2016 - 2019.

b. Debt to asset ratio variable with a significance level of $0.107(10.7 \%)$, which means the value is greater than the significance level of $0.05(5 \%)$. This shows that the debt to asset ratio does not have a significant effect on the stock prices of pharmaceutical companies listed on the Indonesia Stock Exchange for the period 2016 - 2019. This can be due to the poor quality of equity management in pharmaceutical companies.

c. The variable return on equity with a significance level of $0.000(0 \%)$, which means the value is smaller than the significance level of $0.05(5 \%)$. This shows that return on equity has a significant effect on the stock prices of pharmaceutical companies listed on the Indonesia Stock Exchange for the period 2016 2019.

\section{Suggestion}

Based on the results of this study, the suggestions that can be given by the author are as follows:

1) To pay more attention to the value of the Current Ratio, because the value of the Current Ratio partially has a significant effect on stock prices as described in this study. The higher the Current Ratio value of a company, it means that the company can be considered as having good finances and can attract more profits. Companies with good finances can affect the company's share price in the capital market.

2) Not to pay too much attention to the value of the Debt to Asset Ratio, because the Debt to Asset Ratio does not have a partially significant effect on stock prices as has been proven in this study.

3) To pay more attention to the value of Return On Equity, because Return On Equity has a partially significant effect on Stock Prices. This ratio is used to measure how much net profit will be generated from each rupiah of funds invested in total equity. The higher the Return On Equity value, the higher the interest of potential investors to buy the company's stock price, this certainly has an effect in the form of an increase in the company's stock price. 


\section{Daftar Pustaka}

Basalama, I. S., Murni, S., dan Sumarauw, J. S. B. (2017). Pengaruh Current Ratio, DER Dan ROA Terhadap Return Saham Pada Perusahaan Automotif dan Komponen Periode 2013-2015. Jurnal Emba, 5(2). https://doi.org/15 Maret 2020

Desmond, W. (2014). Analisis Fundamental Saham Edisi Kedua. Exceed.

Harahap, S. S. (2015). Analisis Kritis Atas Laporan Keuangan. Rajawali Pers.

Herry. (2016). Analisis Laporan Keuangan. PT. Bumi Aksara.

Kasmir. (2016). Analisis Laporan Keuangan. Rajawali Pers.

Tumonggor, M., Murni, S., dan Rate, P. V. (2017). Analisis Pengaruh Current Ratio, Return On Equity, Debt To Equity Ratio Dan Growth Terhadap Return Saham Pada Cosmetics And Household Industry Yang Terdaftar Di BEI Periode 2010-2016. Jurnal Emba. https://doi.org/15 Maret 2020 